\title{
Методичні основи дослідження оцінки ефективності експлуатації та ремонту військової автомобільної техніки
}

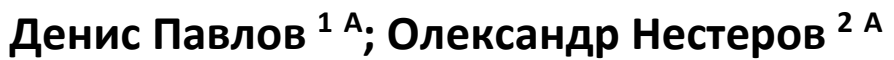 \\ А Національний університет оборони України імені Івана Черняховського, пр-кт Повітрофлотський, 28, г. Київ, 03049, Україна
}

Received: May 9, 2021 | Revised: June 10, 2021 | Accepted: June 30, 2021

DOI: $10.33445 / s d s .2021 .11 .3 .14$

\begin{abstract}
Анотація
У статті розглянуто методичні основи дослідження ефективності експлуатації та ремонту військової автомобільної техніки. Розглянуто проведення комплексу робіт з можливості та доцільності проведення робіт з продовження строку служби, освоєння та проведення ремонту, модернізації за участю вітчизняних підприємств та науково-дослідних установ держави. Проведено аналіз існуючого наукового методичного апарату вирішення завдань обгрунтування вимог до ефективності ремонту. Розглянуто залежність вартісних витрат і технічної досконалості техніки спеціального призначення. Показано, що удосконалення існуючого наукового методичного апарату на основі розробки комплексної методики оцінки, може надати можливість визначити доцільність проведення ремонту, обгрунтування з точки зору працездатності та умов експлуатації, економічних витрат, граничного строку служби, подальшої перспективності військової автомобільної техніки та виробничих можливостей держави.
\end{abstract}

Ключові слова: система експлуатації автомобільної техніки, профілактичні роботи, ефективність системи, відмова, безвідмовність.

\section{Постановка проблеми}

Аналіз світового досвіду підтримання справності військової автомобільної техніки свідчить, що на сьогодні в основі парку провідних країн світу продовжують знаходитися системи, виготовлені ще до початку 90-х років XX століття. При цьому їх частка від загальної кількості приблизно складає до $50 \%$ у США і майже $100 \%$ у країнах Європи, основна частина 3 яких складає військова автомобільна техніка. Результатами практичного застосування військової автомобільної техніки є надмірне використання ресурсного потенціалу існуючого парку, що призводить до не прогнозованого виходу її 3 ладу під час експлуатації як в мирний час так і в особливий період. Істотно зросла небезпека прорахунків і помилок при визначені доцільності та вартості проведення робіт з продовження строку служби автомобільної техніки. Існуючий науковий методичний апарат визначення ефективності експлуатації та ремонту військової техніки втратив свою актуальність, що обумовлено тенденціями розвиту збройної боротьби та форм і способів застосування угруповання військ.

\section{Аналіз останніх досліджень та публікацій}

Дослідженню питань надійності військової автомобільної техніки присвячений цілий ряд робіт, зокрема в роботі [1] проаналізовано вплив кліматичних умов на надійність машин, розглянуто вплив кліматичних факторів на властивості матеріалів і конструктивні особливості машин, але не розглядається вплив ресурсного потенціалу техніки. В роботі

\footnotetext{
1 *Corresponding author: ад'юнкт кафедри технічного забезпечення, e-mail: pavlovdenis81@ukr.net, ORCID: 0000-0003-3348-7655

2 старший науковий співробітник кафедри управління військами, e-mail: nesterov_o_m@ukr.net, ORCID: 0000-0001-5092-6205.
} 
[2-4] наведено метод, розроблений для розрахунків показників структурної надійності систем 3 великим числом елементів. Метод заснований лише на використанні типових структурних схем, що відбивають принципову схему зв'язків між елементами і сформульовані деякі поняття теорії надійності, визначені методи їі підвищення, проведено аналіз якості транспортних машин застосовуються на різних стадіях життєвого циклу, але не враховує характер сучасних операцій.

Головним якістю машин, що застосовуються за призначенням визначено "Надійність". Визначено, що на стадії

\section{Постановка завдання}

Таким чином метою статті $€$ проведення аналізу сучасного стану військової автомобільної техніки, виявити проблемні проектування головною умовою підвищення надійності максимально повний облік особливостей і умов експлуатації. В роботах [5-7] розглянуті проблеми аналізу надійності складальних одиниць, проведено порівняльний аналіз існуючих методів, оцінка їх можливостей та вказано на ряд недоліків кожного методу у цій сфері. В роботі [6] побудовані математичні моделі оптимізації надійності і працездатності технічних систем, які розглядаються на необмеженій інтервалі часу. В основу моделей закладені стан системи. При побудові моделі використовувалися експертні оцінки, що неадаптовані до умов сьогодення.

\section{Виклад основного матеріалу}

У зв'язку із накопиченням великої кількості несправних та 3 вичерпаними строками служби військової автомобільної техніки підтримання справності існуючого парку $\epsilon$ одним із ключових задач в Україні. В умовах високої вартості та необхідної кількості придбання нових зразків, темпу їх придбання та суттєвих часових витрат викликає необхідність проведення комплексу робіт 3 визначення оцінки можливості та доцільності робіт з продовження строку служби, освоєння та проведення ремонту, модернізації за участю вітчизняних підприємств та науководослідних установ України. За останні 20 років виконана велика кількість робіт 3 продовження строку служби, в тому числі з поетапним виконанням. Разом з цим, подальше збільшення строків служби військової автомобільної техніки підвищує ймовірність досягнення граничного стану їх окремими складовими частинами, що викликає необхідність проведення заміни або ремонту [10].

В свою чергу, для вирішення питання щодо проведення ремонту необхідно оцінити доцільність та ефективність його проведення. Відсутність ремонтної документації і питання з експлуатації та ремонту військової автомобільної техніки та надати пропозицій щодо їх вирішення. технічних вимог на ремонт, оскільки майже всі розробники та виробники після розпаду Радянського Союзу знаходяться за межами України, виникає необхідність дослідити ефективність експлуатації та ремонту військової автомобільної техніки без участі їх розробників (виробників). При цьому необхідно вирішити ряд часткових завдань до яких відносяться: визначення обсягу i доцільності проведення ремонту, обґрунтування показників його ефективності, розробка методик та технологічного обладнання для проведення поглибленої діагностики 3 метою виявлення несправностей тощо [9].

Як відомо, ефективність - це кількісна характеристика ступеня досягнення позитивних результатів (ефекту) при використанні об'єкту в конкретних умовах при врахуванні витрат (економічних, трудових, матеріальних, часових тощо). Ефективність експлуатації та проведення ремонту - це комплекс необхідних і достатніх робіт, що проводяться з метою відновлення працездатності складних технічних систем, продовження строку служби, відпрацювання нових технічних рішень по технології 
ремонту, зменшення потреби в новій та занадто дорогій техніці та сприяння економії ресурсів [11]. Поняття ефективності є одним із ключових понять теорії складних систем.

Сучасні складні технічні системи складаються із великої кількості взаємозв'язаних та взаємодіючих між собою складових частин (механічних, електричних, лазерних, радіоелектронних, оптичних, хімічних тощо), які побудовані на використанні певних фізичних, хімічних властивостей та виконують свої функції відповідно до закладених алгоритмів роботи $[7,10,14]$. Кожен тип складних технічних систем, має визначену структуру, яка визначається його призначенням. Разом 3 цим, всі вони мають спільні риси по складу та конструкції, тобто $\epsilon$ типовими представниками складних технічних систем та можуть бути розглянуті з позицій теорії складних систем.

За результатами проведеного аналізу сукупності експлуатаційних властивостей військової автомобільної техніки та їх складових частин, можна зробити висновок, що В якості основного показника при розв'язанні задачі оцінювання зміни у часі технічного стану цієї техніки доцільно розглядати надійність, як найбільш розповсюдженого $[8,14,15]$.

Надійність військової автомобільної техніки - це властивість зберігати у часі значення параметрів в установлених межах, які характеризують його спроможність виконувати свої функції в заданих режимах та умовах використання, технічного обслуговування, ремонтів, зберігання і транспортування військової автомобільної техніки [8]. Надійність $€$ комплексною властивістю, яка в залежності від призначення зразка і умов його використання, характеризується сукупністю властивостей: безвідмовність, довговічність, збережуваність і ремонтопридатність військової автомобільної техніки.

Як відомо, важливою характеристикою якості та надійності військової автомобільної техніки $€$ витрати на їх експлуатацію i ремонти, тобто витрати на підтримку i відновлення їх працездатного стану та ресурсу в процесі використання за призначенням військової автомобільної техніки [9, 11, 16]. У технічній літературі вказується, що витрати праці і коштів на технічне обслуговування і ремонт (ТО і Р) військової автомобільної техніки за час їх експлуатації в 50-80 разів і більше перевищують відповідні витрати на виготовлення. У такому ж приблизно співвідношенні знаходиться і кількість фахівців, зайнятих виготовленням машин, їх обслуговуванням і ремонтом. Наприклад, витрати коштів на ТО і $\mathrm{P}$ військової автомобільної техніки за 10 років їх експлуатації в 67 разів перевищують витрати на їх виготовлення.

При розробці військової автомобільної техніки та їх виготовленні передбачається підтримувати їх працездатний стан і ресурс шляхом проведення певного комплексу робіт, що входять до складу ТО і Р, отже, конструкції військової автомобільної техніки повинні бути пристосовані до цих робіт, причому періодичність останніх і витрати на них треба встановлювати за умови забезпечення оптимального значення ефективності використання машин. Іншими словами, конструкції техніки повинні володіти ремонтопридатністю.

Під ремонтопридатністю військової автомобільної техніки розуміють властивість об'єкта, що полягає в пристосованості до попередження і виявлення причин виникнення відмов, пошкоджень і усунення їх наслідків шляхом проведення технічного обслуговування i ремонтів [8]. Для своєчасного та якісного відновлення працездатності військової автомобільної техніки велике значення має тривалість ремонту, трудомісткість робіт, ступіть уніфікації та стандартизації.

Ефективність ремонту військової автомобільної техніки суттєво залежить від зазначених властивостей надійності, складу контрольованих та неконтрольованих параметрів технічного стану [13, 17]. При цьому, вирішальним фактором обрання надійності для рішення задачі оцінювання 
ефективності проведення ремонту військової автомобільної техніки $€$ ї̈ властивість змінюватися у часі в залежності від фізичних властивостей та умов експлуатації військової автомобільної техніки. Найбільш розповсюдженими показниками надійності для відновлюваних технічних систем, є: частота відмов, інтенсивність відмов, наробіток на відмову, імовірність безвідмовної роботи та комплексні показники надійності військової автомобільної техніки.

Враховуючи, що ці складні технічні системи $€$ виробами спеціального призначення, ії̈ важливою характеристикою $\epsilon$ безвідмовність військової автомобільної техніки, яка у свою чергу, характеризується показником ймовірності безвідмовної роботи. Ймовірність безвідмовної роботи це ймовірність того, що в межах заданого напрацювання відмова об'єкту не відбудеться. Відмова військової автомобільної техніки - це повна або часткова втрата технічною системою працездатного стану. При настанні відмови система не може виконувати задані функції, а параметри його технічного стану виходять за допустимі межі військової автомобільної техніки. Причиною втрати військової автомобільної техніки працездатного стану $\epsilon$ досягнення ними граничного стану, при цьому, різні складові частини досягають свого граничного стану в різний час.

Отже, однією із основних задач ремонту $\epsilon$ відновлення працездатного стану військової автомобільної техніки без зниження вимог до його ймовірності безвідмовної роботи.

Загальні вимоги до рівня надійності військової автомобільної техніки можуть бути пред'явлені на основі вимог до показників ефективності функціонування в процесі експлуатації [11, 16, 18]. В свою чергу, показники ефективності залежать від сукупності тактико-технічних та експлуатаційних характеристик техніки військової автомобільної техніки, що визначають рівень їх технічної досконалості.

В загальному випадку, рівень технічної досконалості В процесі життєвого циклу військової автомобільної техніки має якісний вигляд, показаний на рис. 1, який можна охарактеризувати наступними етапами: поступове нарощування якості в початковий період розробки, виробництва - ділянка 1, постійність - ділянка 2, наступне падіння якості за рахунок морального старіння та досягнення граничного стану в процесі яких ймовірність безвідмовної роботи знижується - ділянка 3.

Для оцінки ефективності ремонту запропоновано використовувати три основних критерії: якості, вартості та технологічності його проведення. Заданий рівень якості обумовлений різними витратами, що формуються під впливом багатьох факторів. Серед таких факторів важливе місце займають технічні вимоги на ремонт техніки спеціального призначення, згідно 3 якими на підприємстві встановлюються певні пропорції між витратами на придбання покупних комплектуючих виробів та витратами на відновлення їх складових частин (деталей, вузлів, блоків, систем тощо). Зміна технічних вимог може змінювати ці пропорції, а відповідно - й вартість ремонту в цілому без суттєвої зміни його якості. Одночасно, чим “жорсткіші" технічні вимоги на ремонт, тобто гранично допустимі величини оціночних параметрів складових частин на ремонт в меншій мірі відрізняються від технічних вимог на їх виготовлення, тим у більшій кількості складових частин будуть замінюватися новими і тим менше буде обсяг робіт по їх відновленню. Отже, рівень якості заданий технічними вимогами на ремонт техніки спеціального призначення, може бути забезпечений різними витратами.

Вище вказані критерії розглядаються окремо один від одного. Тому задачею оцінки ремонту полягає в проведенні аналізу критеріїв з точки зору їх впливу один на одного та знаходження оптимального складу показників, що їх характеризують. Підхід для оптимізації показників оцінки в яких фігурує вартість, пропонується проводити за критерієм "ефективність - вартість". 


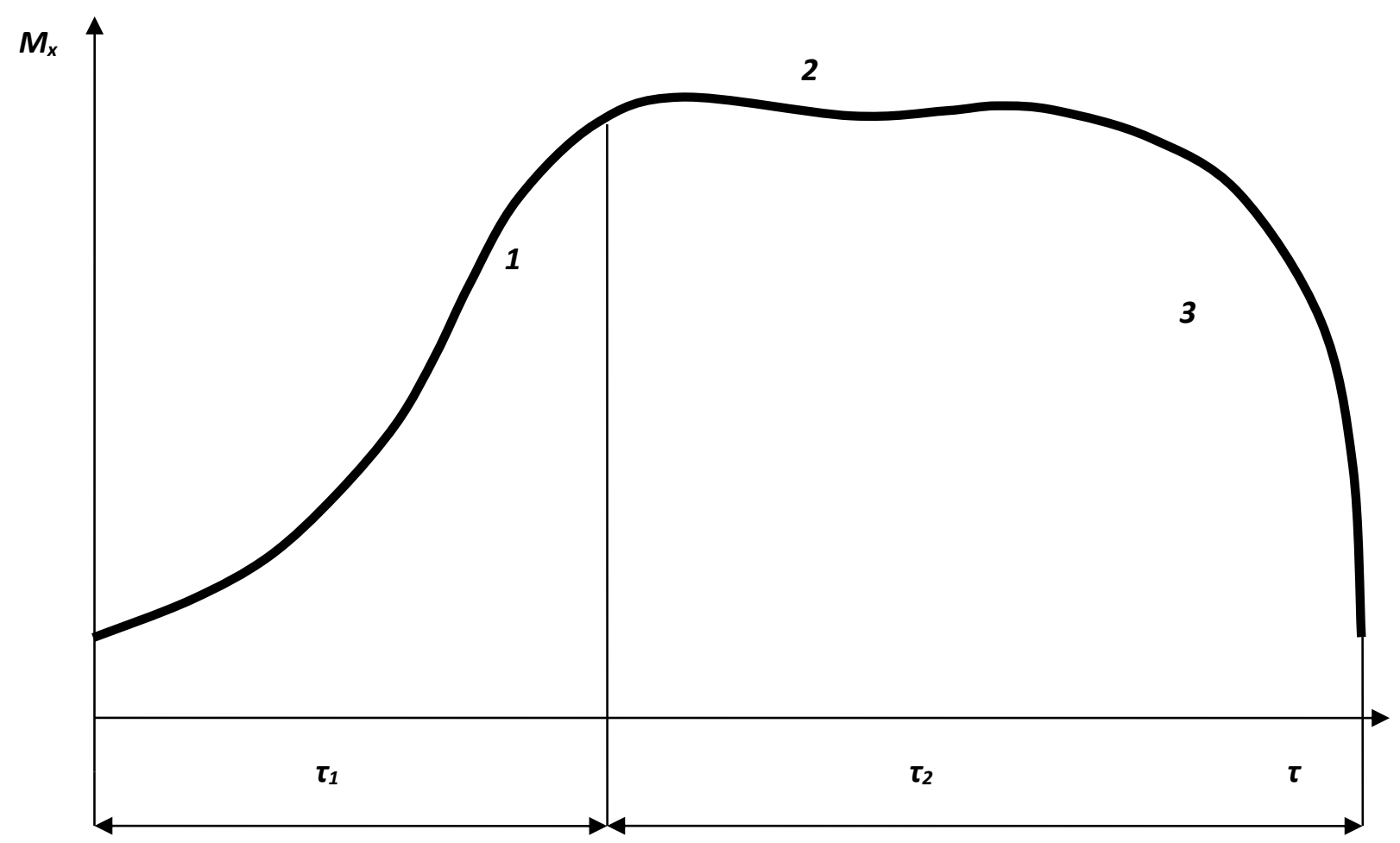

Рисунок 1 - Залежність рівня технічної досконалості впродовж життєвого циклу:

$$
M_{\mathrm{x}} \text { - виробництво, } \tau_{1}, \tau_{2}-\text { експлуатація }
$$

Найкращим $\epsilon$ таке рішення $R_{\text {опт, }}$ яке відповідає мінімальному значенню $C$ та потрібному значенню $W[4]$. У випадку, якщо корисний ефект $W$ та витрати $C$ отримані у вартісному значенні, то $R_{\text {опт }}$ відповідає максимальному значенню різниці між $W$ та $C$, або коли величина $C$ досягає гранично допустимого значення (рис. 2).

Разом з цим, підходи щодо оцінки ефективності ремонту не враховують параметри, які характеризують технічний стан військової автомобільної техніки, підлягають періодичному контролю, а процес визначення параметрів призводить до їх руйнування, обумовлений необхідністю використання руйнівних методів контролю. Як правило, контролю підлягають параметри, що характеризують працездатність систем наведення, управління, підриву та живлення. Для техніки спеціального призначення неконтрольовані складові частини, технічний стан яких необхідно досліджувати, становлять приблизно половину.
Іншою особливістю задачі при виборі науково-методичного апарату оцінювання ефективності експлуатації та ремонту військової автомобільної техніки $€$ те, що військова автомобільна техніка $€$ об'єктом підвищеної небезпеки. Відомо, що поняття безпеки - це властивість об'єкту у випадку втрати працездатного стану не створювати небезпеку для людей. Хоча безпека не входить в поняття надійності, але при застосуванні за призначенням техніки спеціального призначення тісно пов'язана із цим поняттям, а саме коли відмови приводять до умов, що загрожують здоров'ю людини. При цьому треба враховувати, що техніка спеціального призначення може перейти в граничний стан, залишаючись працездатною, якщо ії застосування за призначенням стане не допустимим по вимогам безпеки. Отже, ще однією задачею при проведенні ремонту $\epsilon$ відновлення працездатного стану без зниження вимог до безпеки при експлуатації. 


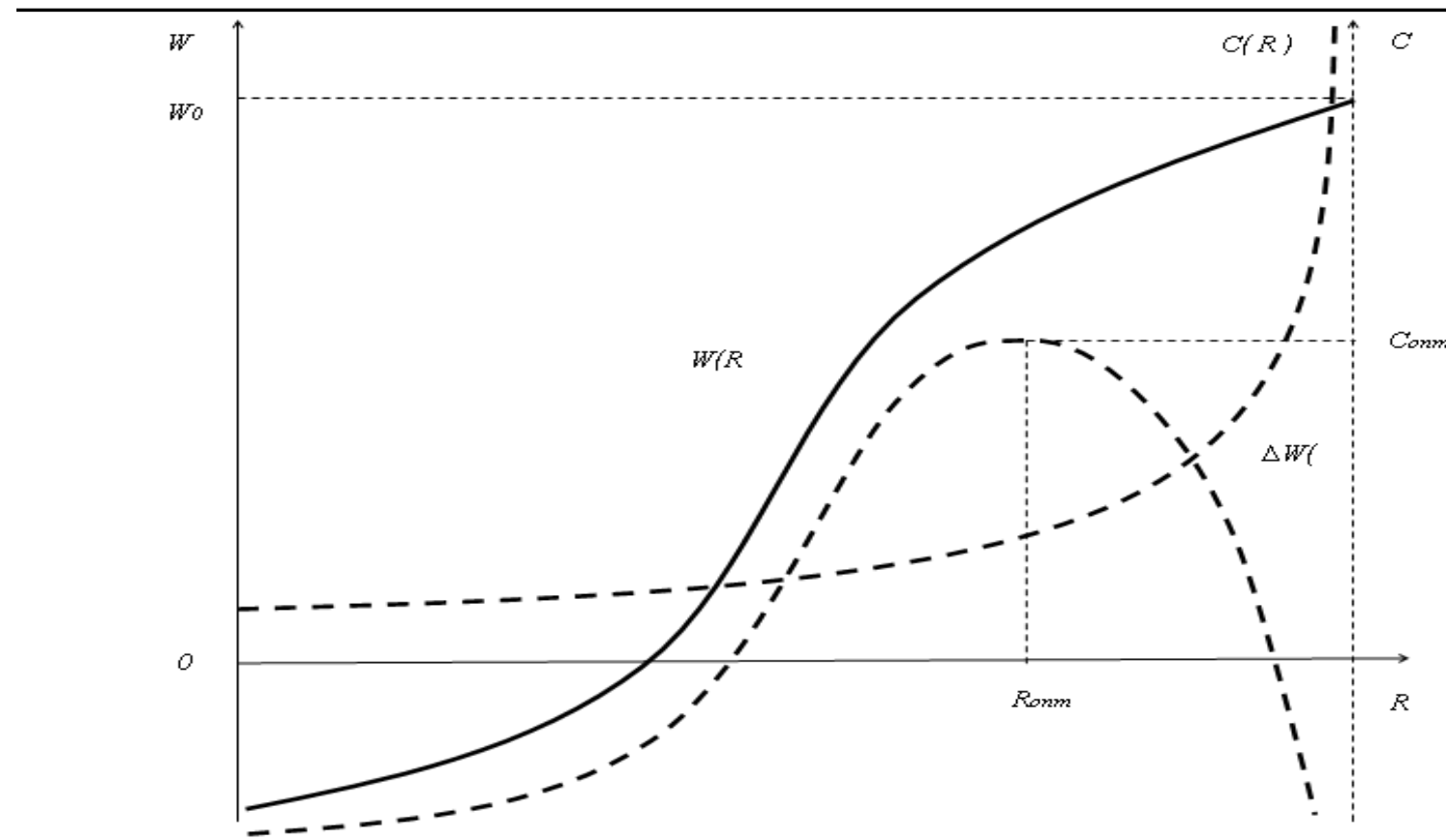

Рисунок 2 - Графіки залежності вартісних витрат $\mathrm{C}(\mathrm{R})$ та

технічної ефективності $\mathrm{W}(\mathrm{R})$ виробу та приріст $\Delta \mathrm{W}(\mathrm{R})=\mathrm{W}(\mathrm{R})-\mathrm{C}(\mathrm{R})$ від величини ПH $\mathrm{R}$, коли $\mathrm{C}$ та $\mathrm{W}$ - значення одного виду

Події, що визначають надійність виробів, $\epsilon$ випадковими, тому особливе місце при оцінюванні надійності систем займають
Таким чином, за результатами аналізу можна зробити висновок про те, що існуючий методичний апарат вирішення завдань обґрунтування вимог до ефективності експлуатації та ремонту військової автомобільної техніки базується на відокремленні завдань 3 подальшим розрахунком необхідних характеристик без урахування їхніх взаємозв'язків, не враховуються особливості призначення та оцінки технічного стану військової автомобільної техніки. Тому, це вимагає удосконалення існуючого методичного методи ймовірнісної та математичної статистик.

апарату на основі розробки комплексної методики оцінки ефективності експлуатації та ремонту військової автомобільної техніки, що дасть можливість визначити доцільність проведення ремонту, обґрунтованого з точки зору працездатності та безпеки в експлуатації, економічних витрат, граничного строку служби, подальшої перспективності військової автомобільної техніки та виробничих можливостей (обладнання, технологій, кваліфікований персонал) підприємств України.

\section{Список використаних джерел}

1. Хачатурян С.Л. Вплив кліматичних факторів на Надійність будівельно-дорожніх машин / Хачатурян С.Л // Наукові записки. - 2013. - Вип.13. С. 3-10.

2. Зевін Л.І. Розрахунок показників надійності технічних систем методом типових структурних схем / Зевін Л.І., Кроль Г.Г. // Journal of Mechanical Engineering. - 2019. - vol. 22, no.

3. Васенёв М. Ю. Оцінка надійності АСУ форвардера на основі різних мережевих стандартів / Васенёв М.Ю. // International Journal of Open Information Technologies. 2018. - vol. 6, №.3. C. 15-19.

4. Максимов С.Є. Надійність транспортних і технологічних машин: формування та 
реалізація / Максимов С.Є., Лялін А.Н., Бондаренко О.М. // Сучасні проблеми науки та освіти. -2012.

5. Конес С. Г. Методи оцінки показників надійності складних компонентів і систем / Конес С. Г., Хазіева Р. Т. // Сучасні проблеми науки та освіти. - 2015. - № 1 (частина 1)

6. Подцикін Н.С. Метод оптимізації надійності технічної системи в умовах обмеженої інформації / Н. С. Подцикін // Вісник Харківського національного університету. - 2013. - №1089, С. 134-144.

7. Артюшин Л. М. Большие технические системы. Проектирование и управление. / Л. М. Артюшин, Ю. К. Зиатдинов, И.А. Попов, А.В. Харченко // Харьков: Факт, 1997. - $201 \mathrm{c}$.

8. Барзиловича Е. Ю. Надежность и эффективность в технике / Справочник под. Ред. В.И. Кузнецова и Е.Ю. Барзиловича. - Т.8. - Эксплуатация и ремонт. - М.: Машиностроение, 1990. $320 \mathrm{c.}$

9. Дедков В. К., Северцев Н. А. Основные вопросы эксплуатации сложных систем. М.: Высшая школа, 1976. - 406 с.

10. Морозенко І. П. Основы теории комплексного обоснования требований к техническим показателям сложных систем // Монографія - К.: 2017. - 234 с.

11. Морозенко І.П. Основы анализа сложных технических систем. Теория и приложения.
Монографія-К.: 2011.-127 с.

12. Кренцель Б. П. Прогнозирование надежности систем с временной избыточностью. - К.: Наукова думка, 1969. -240 c.

13. Кофман А., Крюон Ф. Массовое обслуживание. Теория и приложение / Пер. с фран. - М.: Наука, 1975. - 128 с.

14. Кучера Л. Я. Моделирование показателей надежности технических систем / Л. Я. Кучера, М. В. Копанев, Н. В. Федорова // Современные технологии. Системный анализ. Моделирование. 2013, №32, С. 204208.

15. Линкевич Т. А. Прогнозирование технического состояния $и$ надежности техники специального назначения / Линкевич Т. А., Мозгалеевский А. В., Гаскаров Д. В. - М.: Сов.радио, 1987. - 83 с.

16. Старостина Ж. А. Вопросы повышения надежности машин / Ж. А. Старостина // European Research: Innovation in Science, Education and Technology Сб. ст. по мат.: IX межд. науч.-практ. конф. М., - 2016. - С. 29-31.

17. Трачов А. В. Большие технические системы. Проектирование и управление. / А. В. Трачов, Л. М. Артюшин, Ю. К. Зиатдинов, И. А. Попов. - Харьков: Факт, 1997. - 400c.

18. Черкесов Г. Н. Надежность аппаратнопрограммных комплексов: Учебное пособие. - СПб.: Питер, 2009. - 141 с.

\title{
Методические основы исследования оценки эффективности эксплуатации и ремонта военной автомобильной техники
}

\footnotetext{
Денис Павлов * 1 А; Александр Нестеров 2 А

* Corresponding author: ${ }^{1}$ адъюнкт кафедры технического обеспечения, e-mail: pavlovdenis81@ukr.net, ORCID: 0000-0003-3348-7655 ${ }^{2}$ старший научный сотрудник кафедры, e-mail: nesterov_o_m@ukr.net, ORCID: 0000-0001-5092-6205

А Национальный университет обороны Украины имени Ивана Черняховского, пр-кт Воздухофлотский, 28, г. Киев, 03049, Украина
}

\begin{abstract}
Аннотация
В статье рассмотрены методические основы исследования эффективности эксплуатации и ремонта военной автомобильной техники. Рассмотрены проведения комплекса работ по возможности и целесообразности проведения работ по продлению срока службы, освоения и проведения ремонта, модернизации с участием отечественных предприятий и научноисследовательских учреждений страны. Проведен анализ существующего методического аппарата решения задач обоснования требований к эффективности ремонта. Рассмотрена
\end{abstract}


зависимость стоимостных затрат и технического совершенства техники специального назначения. Показано, что усовершенствование существующего методического аппарата на основе разработки комплексной методики оценки, может позволить определить целесообразность проведения ремонта, обоснование с точки зрения работоспособности и условий эксплуатации, экономических издержек, предельного срока службы, дальнейшей перспективности военной автомобильной техники и производственных возможностей государства.

Ключевые слова: система эксплуатации автомобильной техники, профилактические работы, эффективность системы, отказ, безотказность.

\title{
Methodical bases of research of an estimation of efficiency of operation and repair of military automobile equipment
}

\author{
Denis Pavlov * 1 A; Alexander Nesterov 2 A \\ * Corresponding author: ${ }^{1}$ PhD student, e-mail: pavlovdenis81@ukr.net, ORCID: 0000-0003-3348-7655 \\ ${ }^{2}$ Senior Researcher, e-mail: nesterov_o_m@ukr.net, ORCID: 0000-0001-5092-6205 \\ A National Defence University of Ukraine named Ivan Chernyakhovsky, 28 Povitroflotsky Ave., Kyiv, 03049, Ukraine
}

\begin{abstract}
The methodical bases of research of efficiency of operation and repair of military automobile equipment are considered in the article. A set of works on the possibility and feasibility of work to extend the service life, development and repair, modernization with the participation of domestic enterprises and research institutions of the state. The analysis of the existing methodical apparatus of the decision of problems of substantiation of requirements to efficiency of repair is carried out. The dependence of cost costs and technical perfection of special purpose equipment is considered. It is shown that the improvement of the existing methodological apparatus on the basis of developing a comprehensive assessment methodology can provide an opportunity to determine the feasibility of repairs, justification in terms of performance and operating conditions, economic costs, service life, future prospects of military vehicles and production capacity.
\end{abstract}

Keywords: system of operation of automobile equipment, preventive works, system efficiency, failure, failure-free operation.

\section{References}

1. Khachaturian S. L. (2013) Infusion of climatic factors on the reliability of the road-going cars. Naukovizapiski. Vip. 13. S. 3-10.

2. Zevin L. I., Krol G.G. (2019) Rozrakhunok indicators of the reliability of technical systems by the method of typical structural schemes. Journal of Mechanical Engineering. vol. 22, № 2

3. Vasenev M. Yu. (2018) Assessment of the reliability of the automatic control system of the forwarder on the basis of new cut-out standards. International Journal of Open Information Technologies. vol. 6, № 3. S. 1519.

4. Maksimov S.N., Lyalin A.N., Bondarenko O.M.
(2012) The need for transport and technological machines: the formulation and implementation. Modern problems of science and education.

5. Kones S. G., Khazieva R. T. (2015) Methods for assessing indicators of the reliability of folding components and systems. Modern problems of science and education. No. 1 (part 1)

6. Podtsikin N. S. (2013) The method of optimizing the reliability of technical systems in the minds of the interconnected information. Bulletin of Kharkiv National University. No. 1089, S. 134-144.

7. Artyushin L. M., Ziatdinov Y. K., Popov I. A., 
Kharchenko A. V. (1997) Large technical systems.Design and management. Kharkiv: $201 \mathrm{c}$.

8. Barzilovich E.Yu. Reliability and efficiency in technology / Handbook under. Ed. YOU. T.8. Operation and repair. Moscow: Mashinostroyeniye, 1990. 320 c.

9. Dedkov V.K., Severtsev N.A. The main issues of operation of complex systems. Moscow: Vysshaya Shkola, 1976. 406 c.

10. Morozenko I. P. Fundamentals of the theory of complex substantiation of requirements to technical indicators of complex systems. Monograph, Kyiv: 2017. 234 p.

11. Morozenko I. P. Fundamentals of analysis of complex technical systems. Theory and applications. Monograph. Kyiv: 2011. 127 p.

12. Krenzel B. P. Predicting the reliability of systems with time redundancy. Kyiv: Naukova Dumka, 1969. 240 s.

13. Coffman A., Crewon F. Queuing. Theory and application / Per. with fran. Moscow: Science,
1975. $128 \mathrm{~s}$.

14. Kuchera L. Ya., Kopanev M. V., Fedorova N.V. (2013) Modeling of reliability indicators of technical systems. Modern technologies. System analysis. Modeling. №32, pp. 204208.

15. Linkevich T. A., Mozgaleevsky A. V., Gaskarov D. V. Forecasting the technical condition and reliability of special equipment. Moscow: Sov.radio, 1987. $83 \mathrm{~s}$.

16. Starostina J. A. Questions to increase the reliability of machines. European Research: Innovation in Science, Education and Technology. Art. on mat.: IX int. scientificpractical conf. Moscow, 2016. P. 29-31.

17. Trachov A. V., Artyushin L. M., Ziatdinov Y.K., Popov I.A. Large technical systems.Design and management. Kharkov: Fact, 1997. 400p.

18. Cherkesov G.N. Reliability of hardware and software: A textbook. Saint Petersburg: 2009. $141 \mathrm{~s}$. 